\title{
ORCHIDACEAE L. FAMILY IN THE “IRON GATES” PARK (ROMANIA)
}

\section{Sretco MILANOVICI *}

* Banat National Museum, Natural Science Department, Huniade Square 1, Timişoara, Timiș County, Romania, RO-300697, orchids_mils@yahoo.com,milanovici.sretco@wildcarpathiangarden.com

DOI: 10.1515/trser-2015-0034

KEYWORDS: orchidaceae, biodiversity, inventory, population, conservation, protection, threats, Locvei Mountains, Almăj Mountains, Mehedinţi Plateau, distribution.

\section{ABSTRACT}

Currently, little information is available about the orchid flora in the "Iron Gates" Nature Park, especially due to the lack of the data regarding the detailed geographical distribution and the actual conservation status of species and populations. According to the data provided by the specialist literature for the south-west of Romania, 39 species of orchids are found in this area, of which 29 are in the Danube Gorge (known as Clisura Dunării - "Iron Gates" Nature Park). The field researches regarding the Orchidaceae L. family in the "Iron Gates” Nature Park area have been conducted over a period covering 15 years, from 1996 to 2011. During research conducted in the field I acknowledged the presence of 23 orchid species in the Danube Gorge area and ascertained the presence of new orchid species in the research area: two new species in the Danube Gorge area ("Iron Gates" Nature Park): Epipactis purpurata Sm. and Listera ovata (L.) R. Br.

RÉSUMÉ: La Famille des Orchidacees L. dans le Parc des "Portes de Fer” (Roumanie).

La flore des orchidées dans le Parc Naturel des "Portes de Fer", est peu connue à l'heure actuelle, en particulier à cause du manque de données détaillées sur la répartition géographique et l'état actuel de conservation des genres et des populations. Les données littéraires à propos du sud du Banat (plus exactement, sur le secteur des deux régions protégées étudiées) dénombrent 39 espèces, dont 29 poussant dans la région de la Clisura Dunării (vallée étroite hébergeant des espèces clés, dans la gorge du Danube - Parc Naturel des "Portes de Fer"). La période pendant laquelle les recherches sur le terrain ont été menées sur la famille des Orchidaceae L. dans le Parc Naturel "Portes de Fer”, a été de 15 ans entre 1996 et 2011. Après des recherches personnelles sur le terrain, 23 espèces d'orchidées terrestres ont été confirmées pour le Parc Naturel des "Portes de Fer”. La présence de nouvelles espèces d'orchidées ont été remarquées pour la région étudiée, à savoir, deux nouvelles espèces pour la région de Clisura Dunarii (Parc Naturel des “Portes de Fer”): Epipactis purpurata Sm. Et Listera ovata (L.) R. Br.

REZUMAT: Familia Orchidaceae L. în Parcul Natural Porţile de Fier (Banat, România).

Flora orhideelor din zona Parcului Natural „Porţile de Fier” (Clisura Dunării), în prezent, este puţin cunoscută, lipsind mai ales datele despre răspândirea geografică detaliată, precum şi starea reală de conservare a speciilor şi a populaţiilor de orhidee terestre. Conform datelor din literatura de specialitate pentru zona sudică a Banatului, aici cresc un număr de 39 de specii, din care 29 în zona Clisurii Dunării (Parcul Natural „Porţile de Fier”). Perioada în care s-au desfăşurat cercetările în teren a fost de 15 ani, între 1996 şi 2011. Din cercetările personale în teren s-a confirmat prezenţa a 23 de specii de orhidee pentru Clisura Dunării (Parcul Natural „Porţile de Fier”). S-a constatat prezenţa a noi specii de orhidee pentru zona cercetată, şi anume: două specii noi pentru Clisura Dunării (Parcul Natural „Porţile de Fier”): Epipactis purpurata Sm. şi Listera ovata (L.) R. Br. 


\section{INTRODUCTION}

Currently, little information is available about the orchid flora of the "Iron Gates" area (South-West Romania), especially due to the lack of the data regarding the detailed geographical distribution and the actual conservation status of species and populations.

Orchids are present in a large number of plant associations in Romania, including here the large majority of the natural and semi-natural habitats (except for the steep rocks) from the area studied in the South-West of Romania, but the importance regarding their occurrence, distribution and ecology is usually disregarded. The orchids from the study areas have not been sufficiently researched from a vegetation perspective and the specialist literature emphasizes only few data about several species. The scanty information about these orchids may be linked to several factors, such as their scarcity, the small and scattered populations as well as to the degradation and even extinction of the natural habitats (Savić, 2001).

58 orchid species are growing in Romania according to the data provided by the botanical literature (Flora României/Romanian Flora). For the South-West of Romania (i.e. the surface of the "Iron Gates" Nature Park, as the subject to this study), 39 species of orchids are encountered in this area, of which 29 are in the Danube Gorge (Csürös et al., 1968; Boşcaiu et al., 1971; Roman, 1974; Coste, 1974; Grigore and Coste, 1974, 1975, 1978; Milanovici, 2004, 2006, 2009, 2012; Matacă, 2005).

\section{MATERIAL AND METHODS}

Researches regarding the Orchidaceae L. family in the "Iron Gates" Nature Park, the species inventory, the inventory, distribution, size and dynamics of populations as well as the acknowledgment of the threats with (direct and indirect) impact upon the orchid species and populations have been conducted over a period covering 15 years, from 1996 to 2011.

The main bibliographical source related to the western region of Romania, starting with the basic studies: Rochel - "Plantae Banatus rariores ..." (1828); Heuffel "Enumeratio plantarum in Banatu Temesiensi ...” (1858); Panţiu - „Orchidaceele din România”, studiu monografic/Orchids of Romania. A monographical study (1915); "Flora Republicii Socialiste România”, XII, (Paucă et al., 1972). To understand the biology, ecology and history of native orchid species the following were used as basic works: "The orchids: natural history and classification” (Dressler, 1981); "Terrestrial orchids from seed to mycotrophic plant", (Rasmussen, 1995), and others.

The first research stage consisted of taking samples for archiving purposes (i.e. for herbarium) only from the areas which numerically allowed the sample collection without yet affecting the orchid population. Since, I consider, based on my field researches, that most orchid species are rare or even extremely rare in nature (i.e. in the areas covered by this study), I started to determine the species directly in the field, and during the subsequent research phases, I avoided as far as possible collecting vegetal material for the herbarium in order to avoid potential damage to individuals. Every emergence of species (individuals) and populations has been recorded (genus, place, phonological stage, vegetal association, threats to this genus, and during the last three years, data has been collected by means of GPS devices), and the location where these have been found was pointed out on the relevant work maps. Herbarium material has been lodged in the Banat National Museum, Timişoara. 
The determination of species has been made based on the data provided by "Flora of The Socialist Republic of Romania” XII (Paucă et al., 1972) up to the species level and the nomenclature of taxa that was used has been harmonized with „Flora Europea” (Moore, 1980). Other specialist bibliographical sources have also been used (Soó, 1973; picture-based identification guides; specialist websites).

The synecological characteristics of the orchid species recognized in the research area have been defined based on the principles and methods prescribed by the Central-European Phytocenological School (Braun-Blanquet, 1965).

The determination of the vegetal associations has been made directly in situ, based on the dominance and codominance principles. For denominating the vegetal associations presented within this study, I have used the "Phytocenoses from Romania. Syntaxonomy, structure, dynamics and evolution” monograph (Sanda et al., 2008).

\section{RESULTS AND DISCUSSION}

The first personal research notes, in situ, regarding the presence of the orchid species have been laid down in 1996, in the western part of the Locvei Mountains (the surroundings of Belobreşca Village), being then gradually extended over the entire area of the southern versants of Locvei Mountains, between Şuşca Village and Baziaş Village.

After 2004, the research has been extended across the entire area of the "Iron Gates” Nature Park. Until 2009, I have managed to acknowledge in situ a number of 23 orchid species (Milanovici, 2009) from which two new orchid species in the Danube Gorge, out of the 29 orchid species described by different scientific sources. However, I have not recognized the presence of several orchid species described by certain scientific data in this area.

Henceforth, the study emphasizes the orchid species existing in the research area, according to the data provided by the scientific literature and based on my personal researches (Tab. 1). Brief data have been provided for each individual species, regarding its biology and ecology thereof (i.e. the species sheet), followed by the chronological data concerning the account of the presence of the species, based on personal findings and information provided by the specialist literature, the table showing the vegetal associations where the orchid species have been found (personal observations), the graphic describing the threats to the species and implicitly, to the habitats where the species have been found (personal observations), the multi-annual chart related to the monitoring of the populations' dynamics (for the species with significant representation in the field), the distribution map emphasizing the presence and presentation of the approximate size of the populations within the same species (based on multi-annual observations).

Over the entire period of researches, in parallel with the species inventory process, the populations inventory process (populations size and dynamics as well as the threats to the populations and habitats where these have been found) has also been carried out in order to initiate the control of fluctuations of the orchid species populations with significant numerical presence in the study area. 
Table 1: The orchid flora from the "Iron Gates" Nature Park area, subject to this study (data from scientific literature and personal observations); C - comments, NFP - new for park.

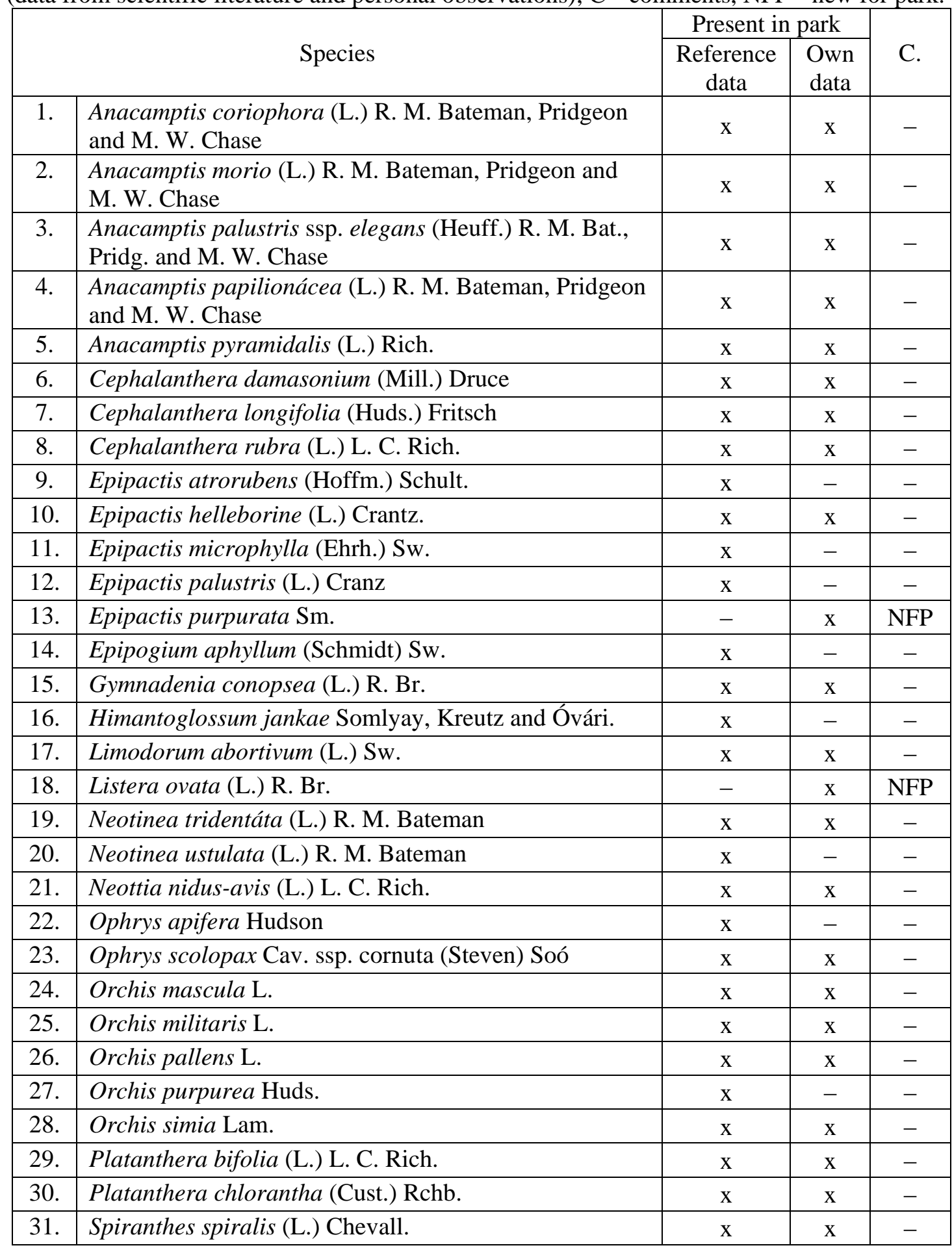


In respect of the analysis and synthetic presentation of the research data, for every species found in the field there have been presented relevant synthetic data (Fig. 2, "the species sheet"), as follows:

- brief data regarding the biology and ecology of the species according to "Romanian Flora” (Flora României); Soó, 1973; Ciocârlan, 2009;

- the chronological data regarding the presence of the species, based on the information provided by the botanical scientific literature and my personal researches, for all species;

- the phenological table regarding the blossom period of the orchid species found in the field (based on my personal notes and considerations, there has been used the simple presentation method synthesized in an explanatory table; Tab. 2);

- the table emphasizing the vegetal associations where the field researches found different orchid species (based on personal observations; there has been used the simple presentation method synthesized in an explanatory table, according to some of my personal considerations; Tab. 3);

- a chart including the potential threats for the species and implicitly for the habitats where the species has been found; I used an imaginary scale from one to 10 where I represented the influence degree of the threats in direct correlation with the habitats where the orchid species have been found (Fig. 4);

- the multi-annual chart regarding the monitoring of the dynamics of populations (for certain orchid species with significant representation, from the numeric perspective; I used my own research method, as follows: firstly, I chose a population of a particular species and I delimited the monitoring area, as follows: in the (imaginary) center of the population I sank deep down into the earth a permanent pole to be used as a bench-mark for the future years (Fig. 1); using a string attached to the pole by one tag, I measured the population length, i.e. $25 \mathrm{~m}$ (monitoring for grasslands), stretching the string to the south; the same principle was applied for the other three directions; at the other tag end of the string (at exact $25 \mathrm{~m}$ length) I fastened in a provisory stick and thus I created a measurable monitoring area, namely a 50 x $50 \mathrm{~m}$ square; as for the forest habitats, I set up a $100 \times 100 \mathrm{~m}$ monitoring measurable area (as a central land mark, I used a marked tree placed exactly in the centre of the orchid population) since the orchid species that characterize the forest phytocenoses are more sporadic and scattered; for each monitoring area I indicated the park area where the population was found, as well as the name of the monitored place the surface, the type of habitat, and the type of the vegetal association (Sanda et al., 2008), as well as the area exposure and slope angle) (Figs 3a, b);

- the distribution map, underlining the presence and description of the approximate size of the populations belonging to the same species (there have been used ArcWiev shapes, processed and specially customized for the two protected areas subject to this study; the presence of the species as well as the size of its population has been indicated by means of a full black or white circle of different sizes which also shows the size of the population, from the numerical perspective; the literary data has been represented by means of a white triangle; Fig. 5);

- synthetic map have been attached to this specific study, as appendixes, describing all species that have been found using both the literary data and my personal observations (Fig. 10). 


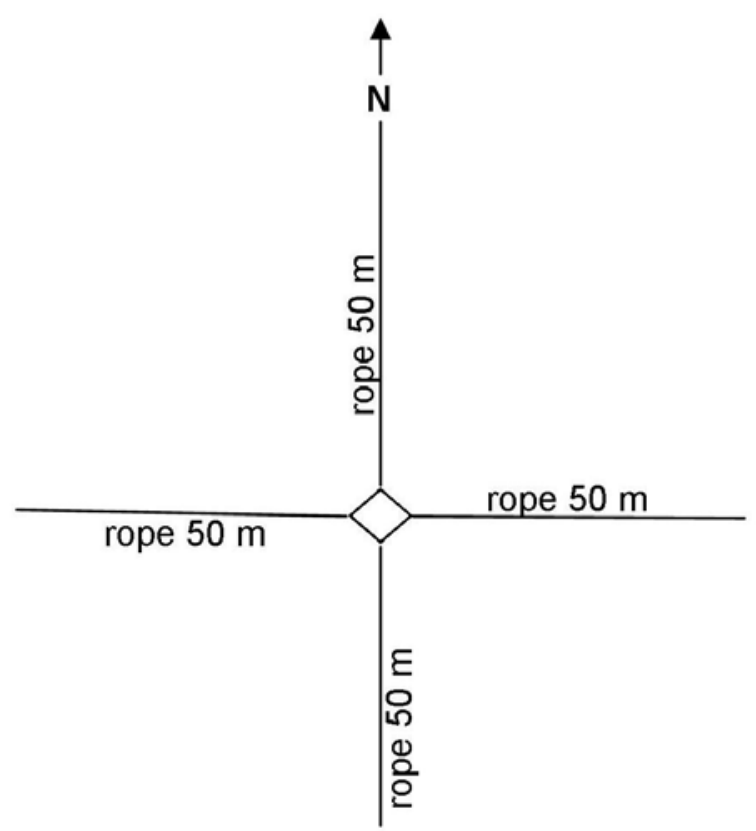

Figure 1: Graphic presentation of the method for monitoring the orchid populations' dynamics. Model of the species sheet (drawn up for every species from all 29).

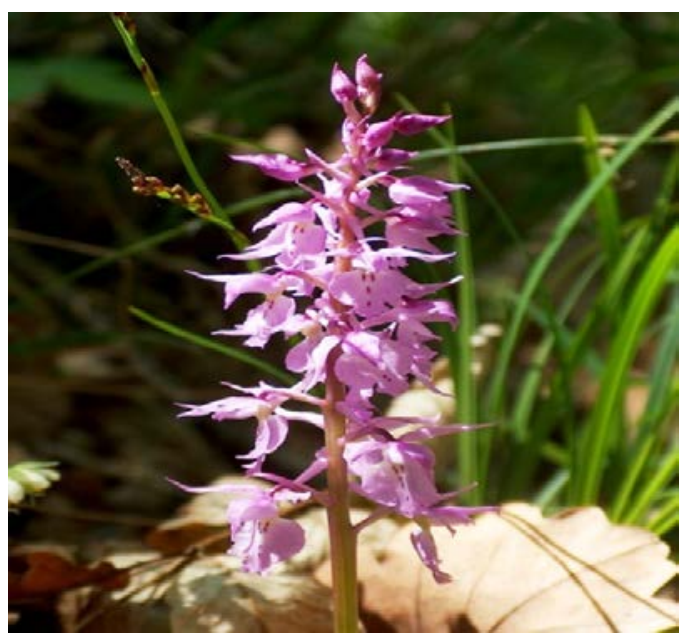

Figure 2: Orchis mascula L. - poranici; in Romania, it is represented by O. mascula L. ssp. signifera (Vest) Soó.

Biological particularities: species coenology: glades, open woods and forest borders, scrubby areas and glades from the mountain regions stretching sometimes up to the alpine area, especially on the calcareous substrates according to "Flora of the Socialist Republic of Romania” (***, 1972); flowering period: IV - VI "Flora of the Socialist Republic of Romania" (***, 1972); biological form: geophyte (Ciocârlan, 2009); number of chromosomes: $2 \mathrm{n}=42$ (Ciocârlan, 2009). 
Ecological particularities: phytogeographical element: sub-Mediterranean (Ciocârlan, 2009); requirements in respect to the climate and soil: mesophyte, light moderate acidophyle (Ciocârlan, 2009).

Status of the species: in the country: frequent (Ciocârlan, 2009).

Data from the scientific literature: Valea Mare - Moldova Nouă (Grigore and Coste, 1975); Moldova Nouă (Herbar Vlaicu N., Muzeul Naţional al Banatului, exs., Vlaicu, 1985).

Personal observation. Belobreşca area: Potok - Belobreşca (1994), road from Belobreşca to Zlatiţa (1998), Pantin Breg (1999), Ceroviţa (1999), Glavčina, Tavančić, Velika Lokva (1999); Ribiş-Divici (1995); Şuşca (1998); Piatra Albă - Radimna (1999); Divici (1999); Sviniţa area: Ielişova (2005), Trescovaţ - Mala Kukujova (2005), Tri Kule (2004); Plavişeviţa (2005); Mala Valley (2004), Ieşelniţa Valley (2005); Orşova area (2007), Alion Hill (2004, 2005); Mare Valley - Moldova Nouă (2006); Sasca Montană (2008); Ciucaru Mic - Dubova (2008); Vârciorova - Faţa Virului (2006); Sfânta Elena (2009); Oglănicului Valley (2008, 2009); Sirinia Valley (2009).

Table 2: Flowering period of Orchis mascula L. in "Iron Gates" Nature Park (table model acording to Savić, 2001).

\begin{tabular}{|c|c|c|c|c|c|c|c|c|c|c|c|c|}
\hline \multicolumn{7}{|c|}{ Flowering period of the following species: Orchis mascula L. } \\
\hline $\begin{array}{c}\text { week one } \\
\left(\begin{array}{c}\text { 7th day of } \\
\text { the month })\end{array}\right.\end{array}$ & & & + & + & & & & & & & \\
\hline $\begin{array}{c}\text { week two } \\
(8-14)\end{array}$ & & & & + & & & & & & & & \\
\hline $\begin{array}{c}\text { week three } \\
(15-21)\end{array}$ & & & & + & & & & & & & & \\
\hline $\begin{array}{c}\text { week four } \\
(22-30,31)\end{array}$ & & & + & + & & & & & & & & \\
\hline Month & I & II & III & IV & V & VI & VII & VIII & IX & X & XI & XII \\
\hline
\end{tabular}

Table 3: Coenological affiliation of Orchis mascula L. occurence in the field (original); according to Sanda et al., 2008.

\begin{tabular}{|c|l|}
\hline Area & \multicolumn{1}{|c|}{ Cenological affiliation } \\
\hline $\begin{array}{c}\text { Western } \\
\text { area }\end{array}$ & $\begin{array}{l}\text { Festuco (rubrae) - Agrostietum Horv. 1951; Quercetum petraeae-cerris Soó } \\
\text { Carpinetum orientalis (Sancev 1961) Csürös et al., 1968; Tilio (argenteae) - } \\
\text { Quercetum petraeae - cerris Soó 1957; Corno-Fraxinetum orni Pop and } \\
\text { Hodişan 1964; Carpino - Fagetum Paucă 1941 sas. banaticum (Borza 1958); } \\
\text { Phyllitidi - Fagetum Vida 1959. }\end{array}$ \\
\hline $\begin{array}{c}\text { Central } \\
\text { area }\end{array}$ & $\begin{array}{l}\text { Festuco (rubrae) - Agrostietum Horv. 1951; Tilio (argenteae) - Quercetum } \\
\text { petraeae - cerris Soó 1957; Carpino - Fagetum Paucă 1941 sas. banaticum } \\
\text { (Borza 1958); Phyllitidi - Fagetum Vida 1959. }\end{array}$ \\
\hline Eastern \\
area & $\begin{array}{l}\text { Quercetum petraeae-cerris Soó 1957; Querco petraea - Carpinetum Soó and } \\
\text { Pocs 1957; Querco - Carpinetum orientalis (Sancev 1961) Csürös et al. } \\
\text { 1968; Sedo maximi - Quercetum frainetto-cerridis B. Jov 1986; Corno - } \\
\text { Quercetum pubescentis Jakucs and Zólyomi ex Mathé and Kovács 1962; } \\
\text { Corno - Fraxinetum orni Pop and Hodişan 1964; Aremonio - Fagetum } \\
\text { banatico - oltenicum Boşcaiu 1970. }\end{array}$ \\
\hline
\end{tabular}


Area: "Iron Gates” Natural Park, western area;

MONITORING for Orchis mascula L.

Location subject to monitoring: Potok Valley (between Belobreşca and Divici villages);

Surface: 100 x $100 \mathrm{~m}$;

Type of habitat: oak forest;

Vegetal association: Quercetum petraeae-cerris, Soó 1957;

Exposure and slope angle: southern, $45^{\circ}$.

Number of flowering specimens

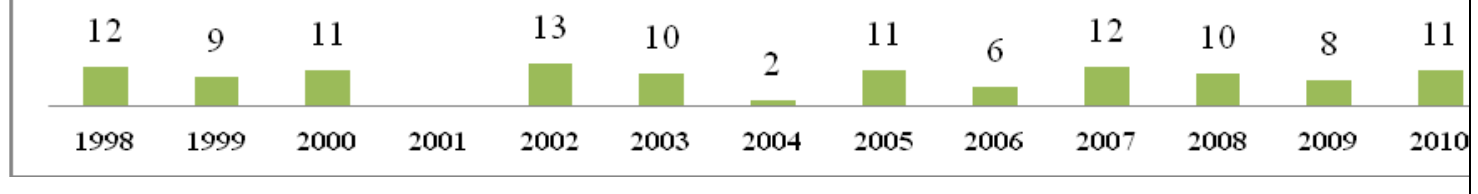

Figure 3a: Monitoring of Orchis mascula - in western area of the "Iron Gates”.

Area: "Iron Gates” Natural Park, eastern area;

MONITORING for Orchis mascula L.

Location subject to monitoring: Vârciorova - Faţa Virului Mic;

Surface: 100 x $100 \mathrm{~m}$;

Type of habitat: oak forest;

Vegetal association: Corno-Quercetum pubescentis Jakucs and Zólyomi ex Mathé and

Kovács 1962;

Exposure and slope angle: south-western, $45^{\circ}$.

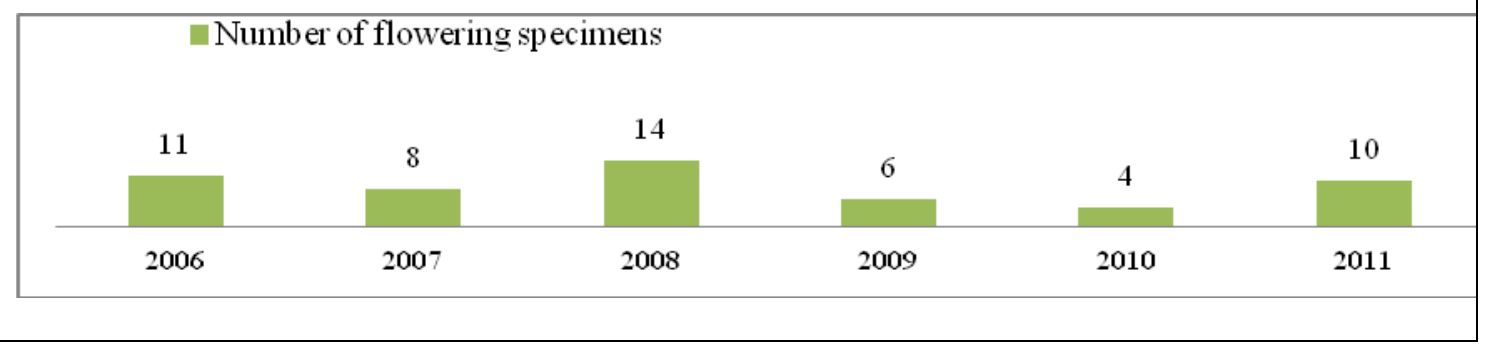

Figure 3b: Monitoring of Orchis mascula - in western area of the "Iron Gates.

In the analytical section dedicated to all orchid species found in the research area, I approached different aspects related to the sustainable preservation and protection of the orchid species from the two protected areas that are the subject of this study, as follows:

I presented the coenotaxonomic affiliation of the orchid species (a table-based presentation specifying the number of orchid species I found in the field for every vegetal association that has been described, followed by graphic representations, table 4); 


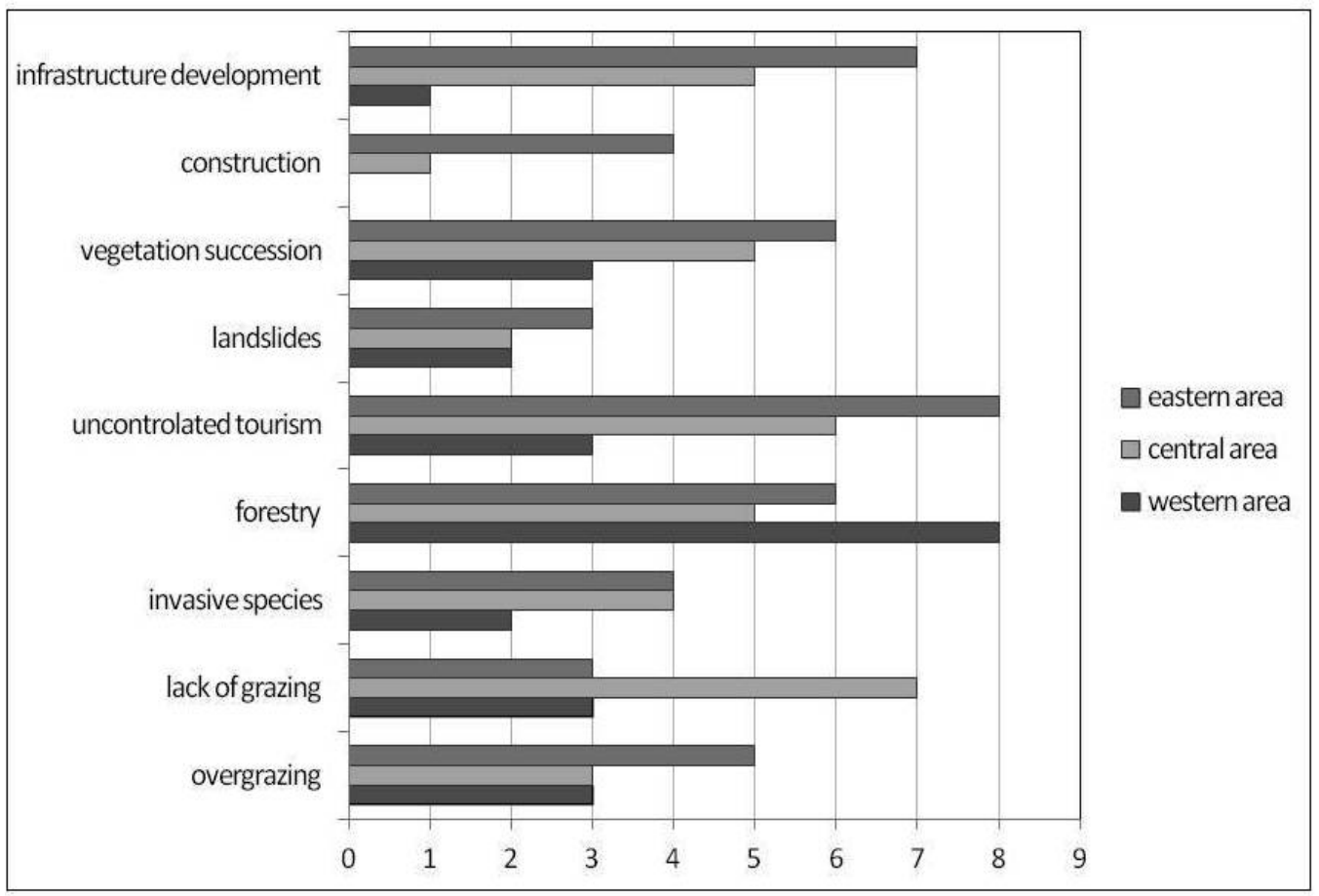

Threats PNPF - Species: Orchis mascula L.

Figure 4: Threats for Orchis mascula L. - for “Iron Gates” Nature Park (original).

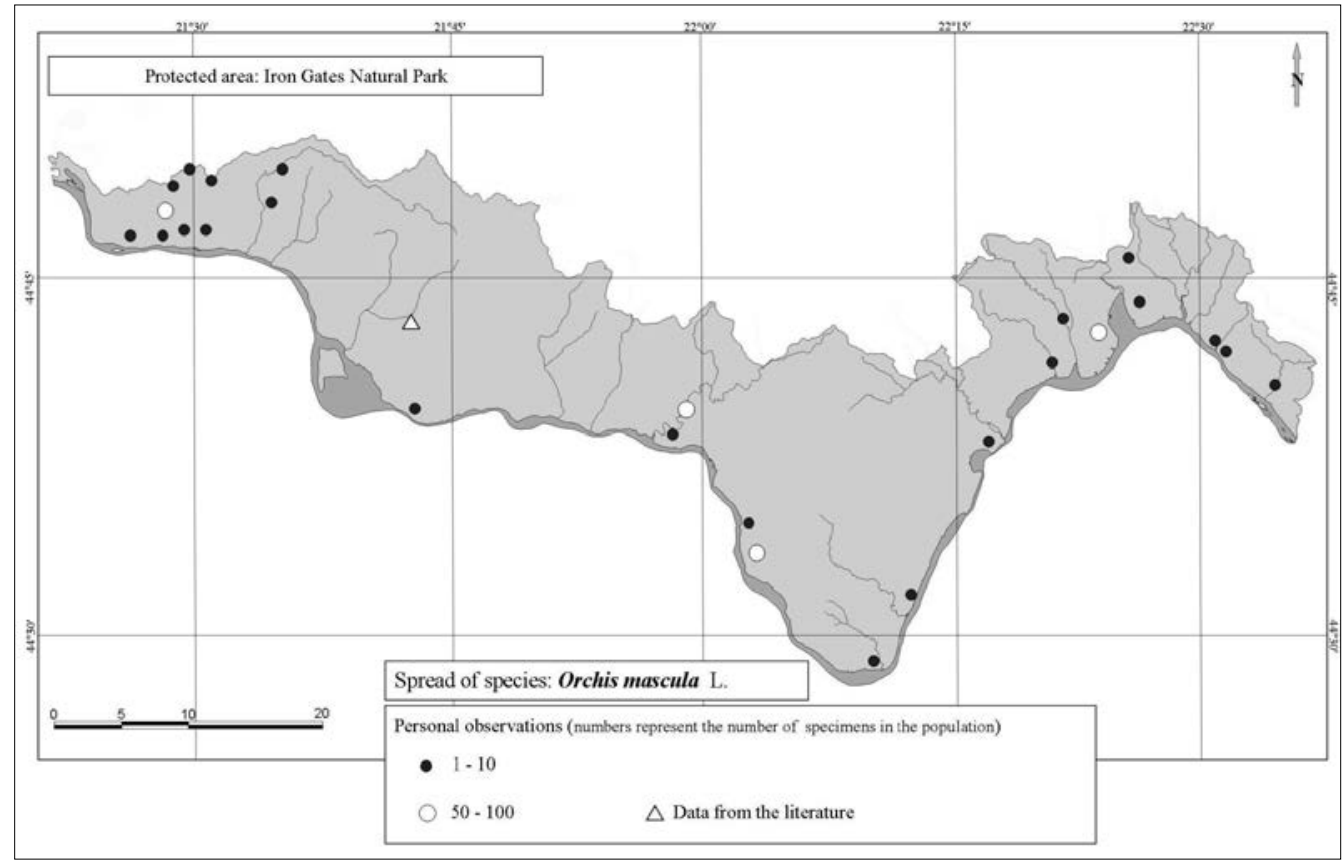

Figure 5: Distribution of the species Orchis mascula L. - "Iron Gates” Nature Park (original). 
Table 4: Number of orchid species I found in the field for each vegetal association (original; acording to Sanda et al., 2008).

\begin{tabular}{|l|c|}
\hline \multicolumn{1}{|c|}{$\begin{array}{c}\text { Vegetal } \\
\text { association }\end{array}$} & $\begin{array}{c}\text { No. of } \\
\text { orchid } \\
\text { species }\end{array}$ \\
\hline Carpino - Fagetum Paucă 1941 sas. banaticum Borza, 1958 & 13 \\
\hline Danthonio - Chrysopogonetum Boşcaiu, 1972 & 9 \\
\hline Festucetum valesiaco - rupicolae Csürös and Kovács, 1962 & 9 \\
\hline Festuco (rubrae) - Agrostietum Horv., 1951 & 9 \\
\hline Quercetum petraeae-cerris Soó, 1957 & 6 \\
\hline Danthonio-Brachypodietum pinnati Soó, 1946 & 5 \\
\hline Querco petraea - Carpinetum Soó and Pocs, 1957 & 5 \\
\hline Festucetum valesiacae (Danon 1962) Borisavljević et al., 1955 & 4 \\
\hline Phyllitidi - Fagetum Vida, 1959 & 4 \\
\hline Querco - Carpinetum orientalis (Sancev 1961) Csürös et al., 1968 & 4 \\
\hline Medicagini minimae - Festucetum valesiacae Wagner, 1941 & 4 \\
\hline Chrysopogonetum grylli praemoesicum Roman, 1974 & 3 \\
\hline Corno-Fraxinetum orni Pop and Hodişan, 1964 & 3 \\
\hline Corno-Quercetum pubescentis Jakucs and Zólyomi ex Mathé and Kovács, 1962 & 3 \\
\hline Epipacteto - Fagetum Resmeriţă, 1972 & 3 \\
\hline Sedo maximi - Quercetum frainetto-cerridis B. Jov, 1986 & 3 \\
\hline Thymo pannonici - Chrysopogonetum grylli Doniţă et al., 1992 & 3 \\
\hline Filagini - vulpietum Oberd., 1938 & 2 \\
\hline Peucedano rocheliani - Molinietum caeruleae Boşcaiu, 1965 & 2 \\
\hline Quercetum farnetto - cerris Rudski 1949 sas. banaticum Pop I., 1967 & 2 \\
\hline Tilio (argenteae) - Quercetum petraeae - cerris Soó, 1957 & 2 \\
\hline Trifolio (repens) - Lolietum perennis Kripelova, 1968 & 1 \\
\hline Aremonio - Fagetum banatico - oltenicum Boşcaiu, 1970 & 1 \\
\hline Agrostio-Festucetum valesiacae Borisavljević et al., 1955 & 1 \\
\hline Cotino - Carpinetum orientalis Csürös et al., 1968 & 1 \\
\hline Filipendulo - Geranietum palustris Koch, 1926 & 1 \\
\hline Geranio macrorrhizae - Fagetum (Borza, 1933) Soó, 1964 & 1 \\
\hline Hieracio pilosellae - Festucetum valesiaceae Vučković, 1991 & 2 \\
\hline Junco - Molinietum Preising, 1951 & 19 \\
\hline Scirpo - Phragmitetum Koch W., 1926 & 19 \\
\hline
\end{tabular}




\section{Vegetal associations and orchids in the research area}

From the vegetation perspective, the orchids in the research area have not been sufficiently studied (Matacă, 2005, has found five species in the field and he refers to the cenological affiliation for 29 species), going no further than the alliance level; as for the Locvei Mountains, Coste, 1974, points to the presence of 15 orchid species (from which he managed to acknowledge only 11 species in the field), adding for most of the species the coenological affiliation up to the level of association.

The scanty data about the orchids may be linked to several factors, such as their scarcity and the small and scattered populations. Based on my personal observations (as well as the very few official data regarding the presence of the orchid species in different vegetal associations), the orchids have been found in 30 vegetal associations (Tab. 4).

Considering the size of the orchid populations, I have tried to provide a more accurate account regarding their exact number, according to the multi-annual data that have been gathered till now (there has been used the graphic simple presentation method, based on my personal determinations) (Figs. 6 and 7);

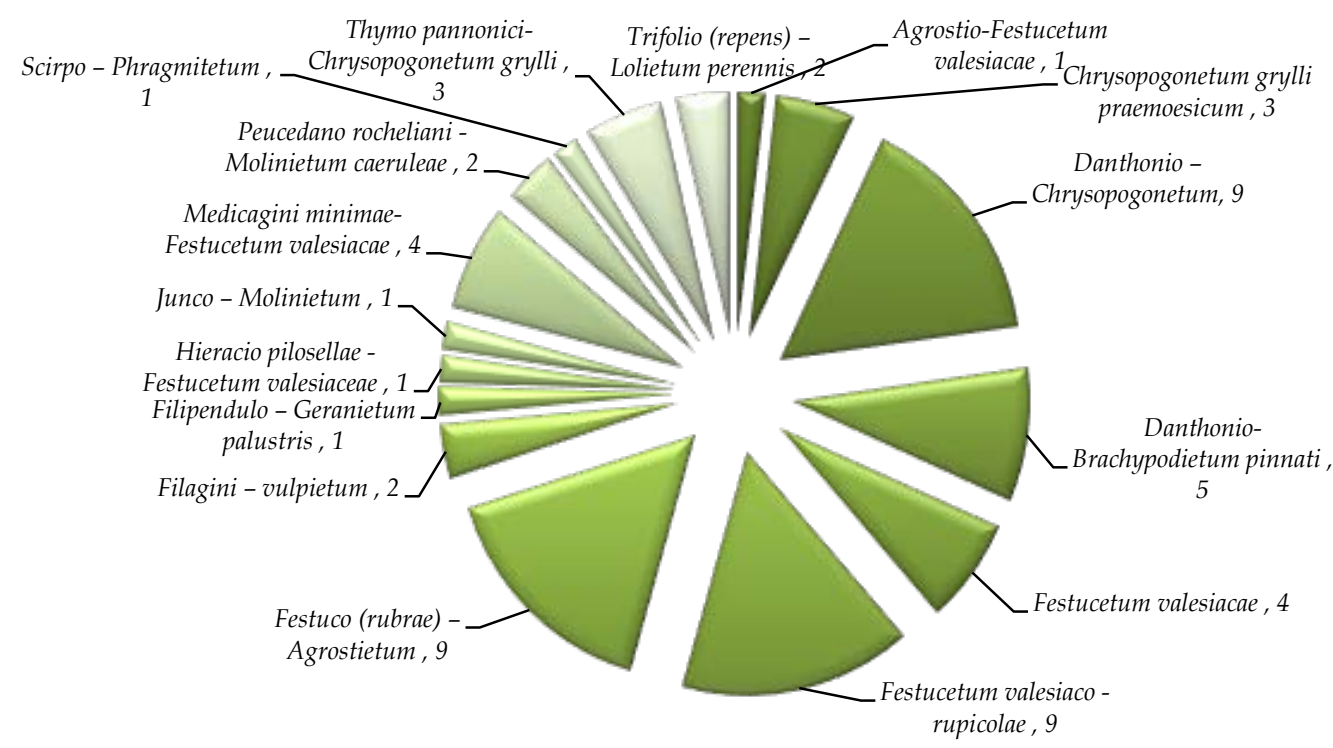

Figure 6: Number of the orchid species in certain habitats, such as grasslands and meadows in the Danube Canyon (vegetal associations according to Sanda et al., 2008).

Due to the fact that most orchid species blossom during the late spring or early summer, I have inserted two graphic representations that explain the number of species that blossom in the research area (graphic according to Savić, 2001, Fig. 8).

I have depicted, in a tabular manner, the most important threats for the orchid species which I found in the field, using a synthetic scale from one to five (in order to express the degree of influence) and I have also added several personal considerations regarding the threat status and the natural recovery process of the ecosystem (habitat) that has been affected; all the threats described in the table have been individually detailed for every protected area subject to my research, being also accompanied by numerous original photos (Tab. 5); 
Taking into account the fact that most orchid species are rare, I drew up a table identifying their status, based on several criteria (according to IUCN; according to Oltean et al. (1994); according to Dihoru and Negrean (2009); their preservation status, according to the Management Plans applicable in the park; according to CITES) as well as their status and condition (based on an individual analysis), according to my personal opinion (Tab. 6).

After an analysis of the threats and the status of the species, I decided to set forth a number of sustainable preservation measures (for every area of the two parks subject to study, complementary to the measures presented by the PNPF administration in Management Plans).

Combining and analyzing the data collected in the field and the relevant information provided by the specialist literature (regarding the presence, the status of populations and the threats to the orchid species) I also put forth appropriate solutions for preservation, suggesting the inclusion of several areas from the "Iron Gates" Nature Park (which currently are not considered as such) into the integral protection area.

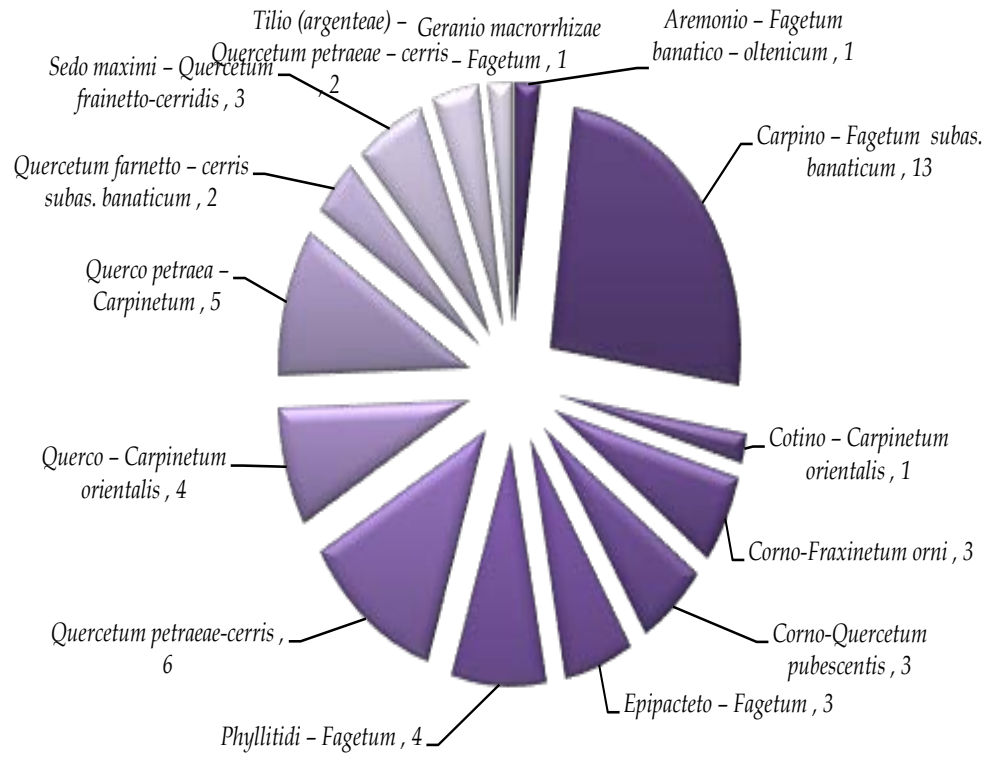

Figure 7: Number of the orchid species in certain habitats, such as forests and scrubby areas in the Danube Canyon (vegetal associations according to Sanda et al., 2008).

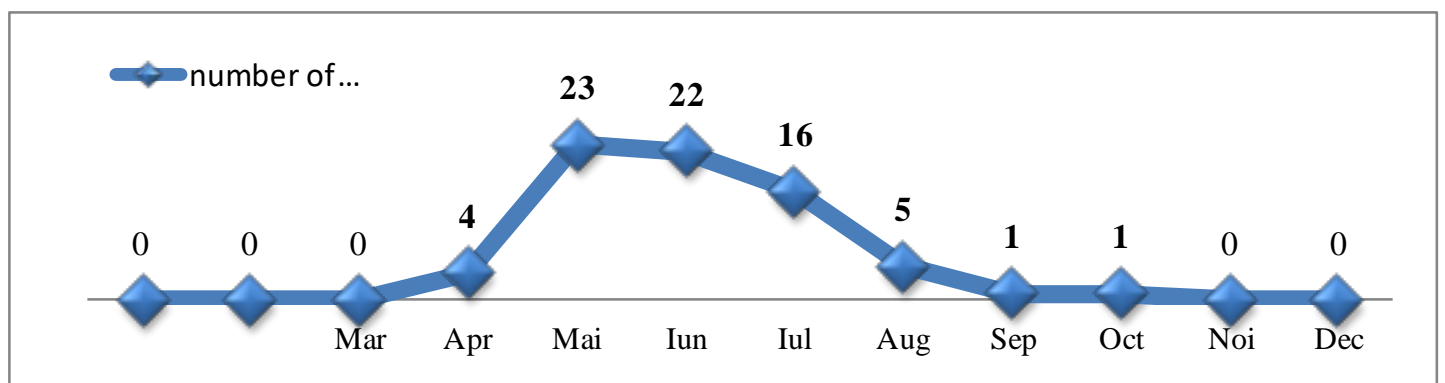

Figure 8: Flowering calendar for the orchid species in “Iron Gates” Natural Park (Savić, 2001). 


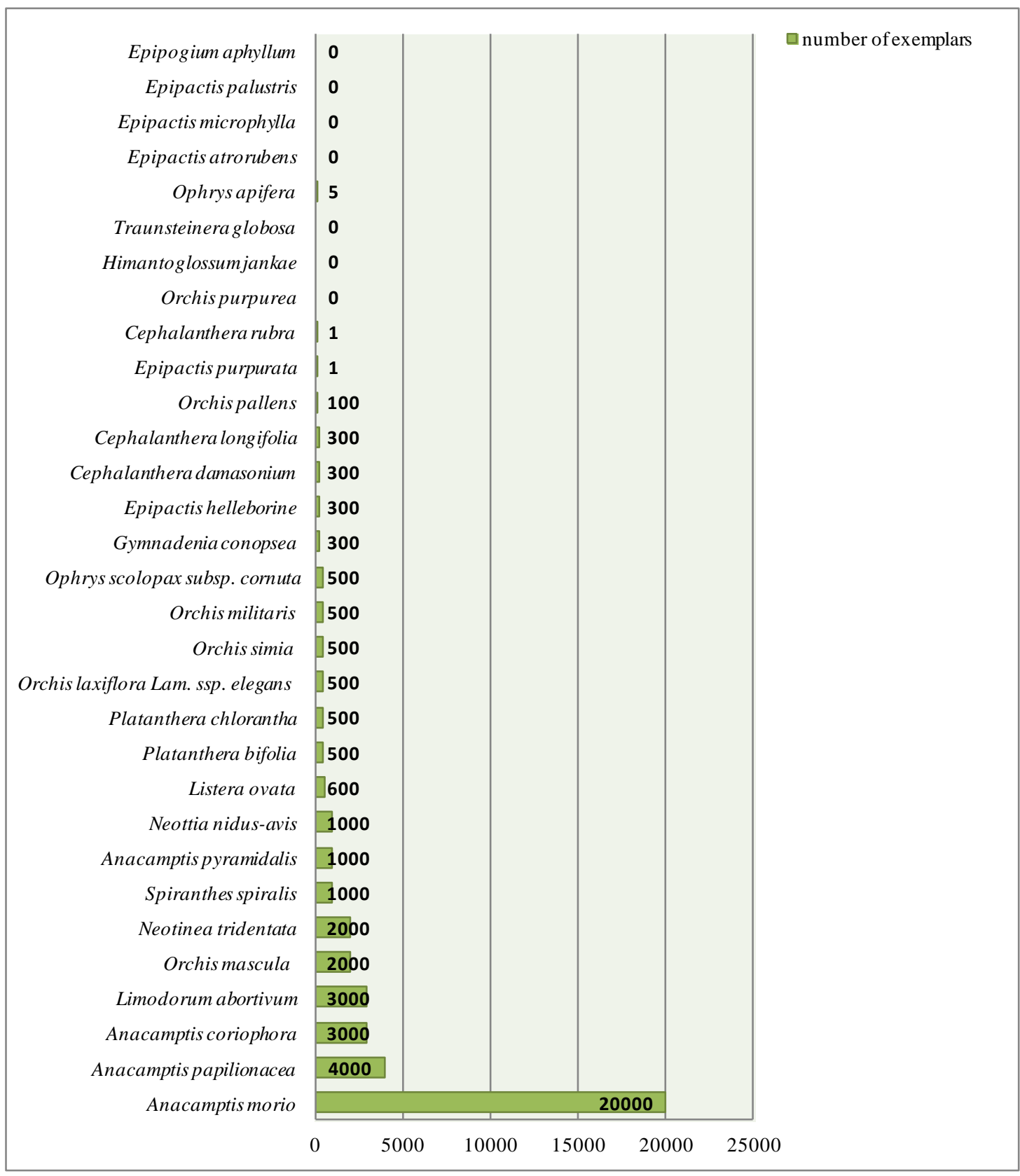

Figure 9: Estimated number of individuals (average years of research from 1998 to 2014) for the Danube Gorge. 
Table 5: Threats to the (habitats) orchid species in "Iron Gates” Nature Park.

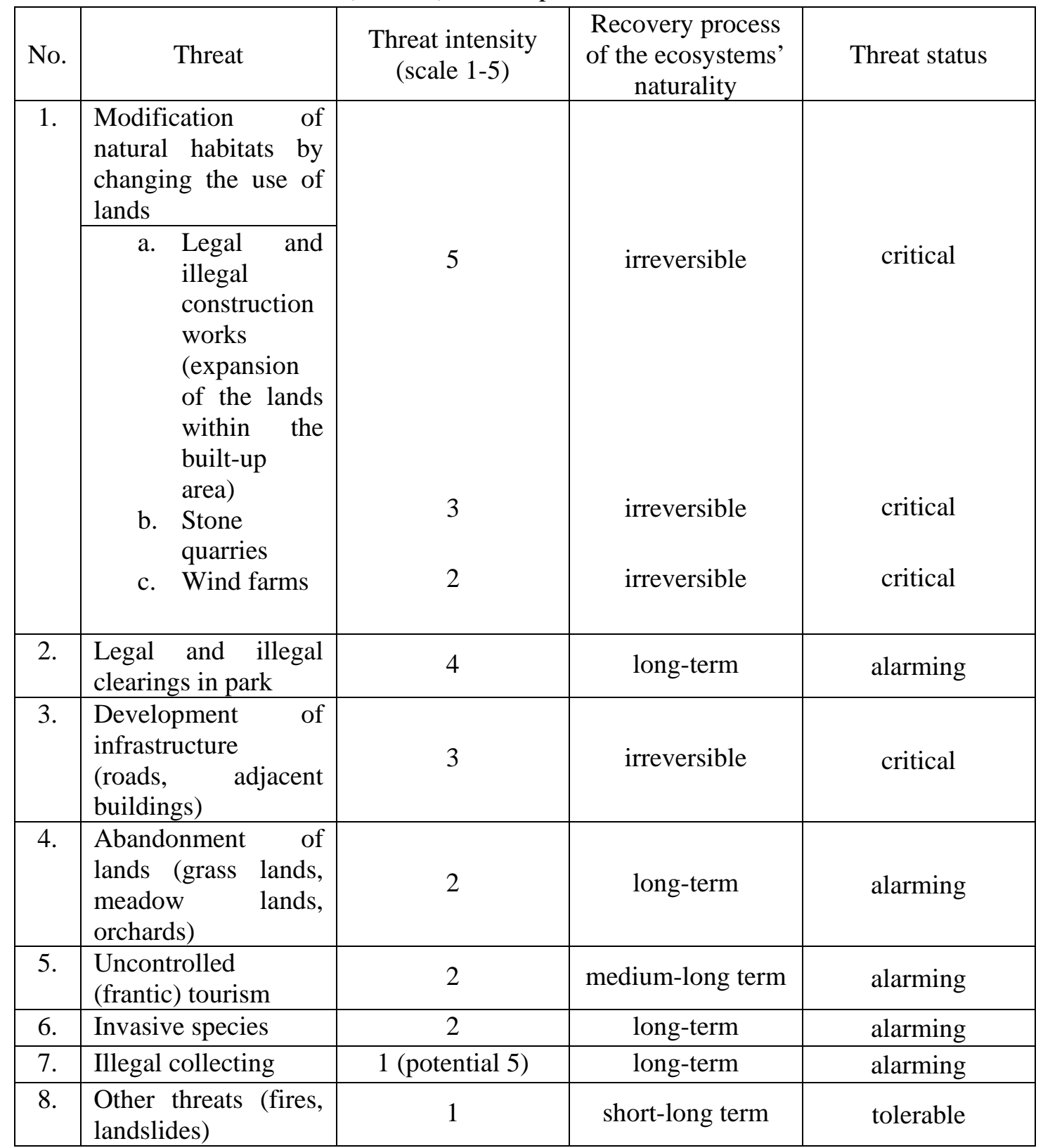


Table 6: The status of the orchid species from the two protected areas, subject to this study; CR - critically endangered, EN - endangered, VU - vulnerable, V/R - vulnerable/rare, $\mathrm{R}$ - rare, NT - non-threatening, DD - insufficiently known; Legend (of the table): 1. IUCN 2011. IUCN Red List of Threatened Species. Version 2011.1., www.iucnredlist.org. Downloaded on 22 October 2011 (* - no information in the IUCN database); 2. Dihoru and Negrean (2009): The Red Data Book of Vascular Plants of Romania (Cartea Roşie a plantelor vasculare din România). Romanian Academy Publishing House, Bucharest; 3. Oltean et al., I/1994. The Red List of the Superior Plants from Romania (Lista Roşie a plantelor superioare din România). Romanian Academy - Institute of Biology, St. Sin. Doc. Ec., Bucharest; 4. ***, Administration of "Iron Gates" Natural Park (2008, 2011): Management Plan of the "Iron Gates" Natural Park, Orşova (brief data); 5. CITES, 2011. http://www.cites.org/eng/app/appendices.php accessed on October 25th $2011\left(^{*},-\right.$ protected); 7. Personal considerations (based on the data provided by the scientific literature and based on personal researches carried out over 15 years of study in the field); NRB - National red Book 2009, NRL - National Red List 1995, PC - Personal Considerations, PNPF - Statute PNPF.

\begin{tabular}{|c|l|c|c|c|c|c|c|}
\hline \multicolumn{1}{|c|}{ Species } & 1 & 2 & 3 & 4 & 5 & 6 \\
\hline 1. & $\begin{array}{l}\text { Anacamptis coriophora } \\
\text { (L.) R. M. Bateman, Pridgeon and M. W. } \\
\text { Chase }\end{array}$ & - & - & $\mathrm{R}$ & - & $\mathrm{X}$ & $\mathrm{R}$ \\
\hline 2. & $\begin{array}{l}\text { Anacamptis morio } \\
\text { (L.) R. M. Bateman, Pridgeon and M. W. } \\
\text { Chase }\end{array}$ & - & - & $\mathrm{R}$ & - & $\mathrm{X}$ & $\mathrm{NT}$ \\
\hline 3. & $\begin{array}{l}\text { Anacamptis palustris ssp. elegans } \\
\text { (Heuff.) R. M. Bat., Pridg. and M. W. Chase }\end{array}$ & - & - & $\mathrm{R}$ & - & $\mathrm{X}$ & $\mathrm{CR}$ \\
\hline 4. & $\begin{array}{l}\text { Anacamptis papilionácea } \\
\text { (L.) R. M. Bateman, Pridgeon and M. W. } \\
\text { Chase }\end{array}$ & - & $\mathrm{LR}$ & $\mathrm{R}$ & - & $\mathrm{X}$ & $\mathrm{R}$ \\
\hline 5. & $\begin{array}{l}\text { Anacamptis pyramidalis } \\
\text { (L.) Rich. }\end{array}$ & $\mathrm{LC}$ & - & $\mathrm{V} /$ & $\mathrm{R}$ & $\mathrm{X}$ & $\mathrm{R}$ \\
\hline 6. & $\begin{array}{l}\text { Cephalanthera damasonium } \\
\text { (Mill.) Druce }\end{array}$ & - & - & $\mathrm{R}$ & - & $\mathrm{X}$ & $\mathrm{R}$ \\
\hline 7. & $\begin{array}{l}\text { Cephalanthera longifolia } \\
\text { (Huds.) Fritsch }\end{array}$ & - & - & $\mathrm{R}$ & - & $\mathrm{X}$ & $\mathrm{R}$ \\
\hline 8. & $\begin{array}{l}\text { Cephalanthera rubra } \\
\text { (L.) L. C. Rich. }\end{array}$ & - & - & $\mathrm{R}$ & - & $\mathrm{X}$ & - \\
\hline 9. & $\begin{array}{l}\text { Epipactis atrorubens } \\
\text { (Hoffm.) Schult. }\end{array}$ & $\begin{array}{l}\text { V/ } \\
\text { Epipactis helleborine } \\
\text { (L.) Crantz. }\end{array}$ & $\mathrm{R}$ & $\mathrm{X}$ & $\mathrm{EN}$ \\
\hline 11. & $\begin{array}{l}\text { Epipactis microphylla } \\
\text { (Ehrh.) Sw. }\end{array}$ & - & $\mathrm{R}$ & - & $\mathrm{X}$ & - \\
\hline
\end{tabular}


Table 6 (continued): The status of the orchid species for "Iron Gates" Nature Park, subject to this study.

\begin{tabular}{|c|c|c|c|c|c|c|c|}
\hline 12. & $\begin{array}{l}\text { Epipactis palustris } \\
\text { (L.) Cranz }\end{array}$ & - & - & $\mathrm{R}$ & - & $X$ & - \\
\hline 13. & $\begin{array}{l}\text { Epipactis purpurata } \\
\text { Sm. }\end{array}$ & - & - & $\mathrm{R}$ & - & $X$ & EN \\
\hline 14. & $\begin{array}{l}\text { Epipogium aphyllum } \\
\text { (Schmidt) Sw. }\end{array}$ & - & - & $\mathrm{R}$ & - & $X$ & DD \\
\hline 15. & $\begin{array}{l}\text { Gymnadenia conopsea } \\
\text { (L.) R. Br. }\end{array}$ & - & - & $\mathrm{R}$ & - & $X$ & $\mathrm{R}$ \\
\hline 16. & $\begin{array}{l}\text { Himantoglossum hircinum } \\
\text { (L.) Spreng. }\end{array}$ & - & - & $\mathrm{R}$ & - & $X$ & - \\
\hline 17. & $\begin{array}{l}\text { Limodorum abortivum } \\
\text { (L.) Sw. }\end{array}$ & - & - & $\mathrm{R}$ & - & $X$ & $\mathrm{~V} / \mathrm{R}$ \\
\hline 18. & $\begin{array}{l}\text { Listera ovata } \\
\text { (L.) R. Br. }\end{array}$ & - & - & $\mathrm{R}$ & - & $X$ & VU \\
\hline 19. & $\begin{array}{l}\text { Neotinea tridentáta } \\
\text { (L.) R. M. Bateman, Pridgeon and M. W. } \\
\text { Chase }\end{array}$ & - & - & $\mathrm{R}$ & - & $X$ & $\mathrm{R}$ \\
\hline 20. & $\begin{array}{l}\text { Neotinea ustulata } \\
\text { (L.) R. M. Bateman, Pridgeon and M. W. } \\
\text { Chase }\end{array}$ & - & - & $\mathrm{R}$ & - & $X$ & - \\
\hline 21. & $\begin{array}{l}\text { Neottia nidus-avis } \\
\text { (L.) L. C. Rich. }\end{array}$ & - & - & $\mathrm{R}$ & - & $X$ & $\mathrm{R}$ \\
\hline 22. & $\begin{array}{l}\text { Ophrys apifera } \\
\text { Hudson }\end{array}$ & - & - & $\mathrm{R}$ & - & $X$ & - \\
\hline 23. & $\begin{array}{l}\text { Ophrys scolopax Cav. ssp. Cornuta } \\
\text { (Steven) Soó }\end{array}$ & - & CR & $\mathrm{R}$ & - & $X$ & VU \\
\hline 24. & $\begin{array}{l}\text { Orchis mascula } \\
\text { L. }\end{array}$ & - & - & $\mathrm{R}$ & - & $X$ & $\mathrm{R}$ \\
\hline 25. & $\begin{array}{l}\text { Orchis militaris } \\
\text { L. }\end{array}$ & - & - & $\mathrm{R}$ & - & $X$ & $\mathrm{~V} / \mathrm{R}$ \\
\hline 26. & $\begin{array}{l}\text { Orchis pallens } \\
\text { L. }\end{array}$ & - & CR & $\mathrm{R}$ & - & $X$ & $\mathrm{E}$ \\
\hline 27. & $\begin{array}{l}\text { Orchis purpurea } \\
\text { Huds. }\end{array}$ & - & - & $\mathrm{R}$ & - & $X$ & - \\
\hline 28. & $\begin{array}{l}\text { Orchis simia } \\
\text { Lam. }\end{array}$ & - & - & $\mathrm{R}$ & - & $X$ & VU \\
\hline 29. & Platanthera bifolia (L.) L. C. Rich. & - & - & $\mathrm{R}$ & - & $\mathrm{X}$ & $\mathrm{R}$ \\
\hline 30. & $\begin{array}{l}\text { Platanthera chlorantha } \\
\text { (Cust.) Rchb. }\end{array}$ & - & - & $\mathrm{R}$ & - & $\mathrm{X}$ & $\mathrm{V} / \mathrm{R}$ \\
\hline 31. & Spiranthes spiralis (L.) Chevall. & $-^{*}$ & - & $\mathrm{R}$ & - & $\mathrm{X}$ & $\mathrm{R}$ \\
\hline
\end{tabular}


The following abbreviations have been used within this study:

IGNP - "Iron Gates" Nature Park; IUCN - International Union for Conservation of Nature (in Romanian: Uniunea Internaţională pentru Conservarea Naturii); O. S. - Forest District; U. P. - Production Unit; MMP - Ministry of Environment and Forests.

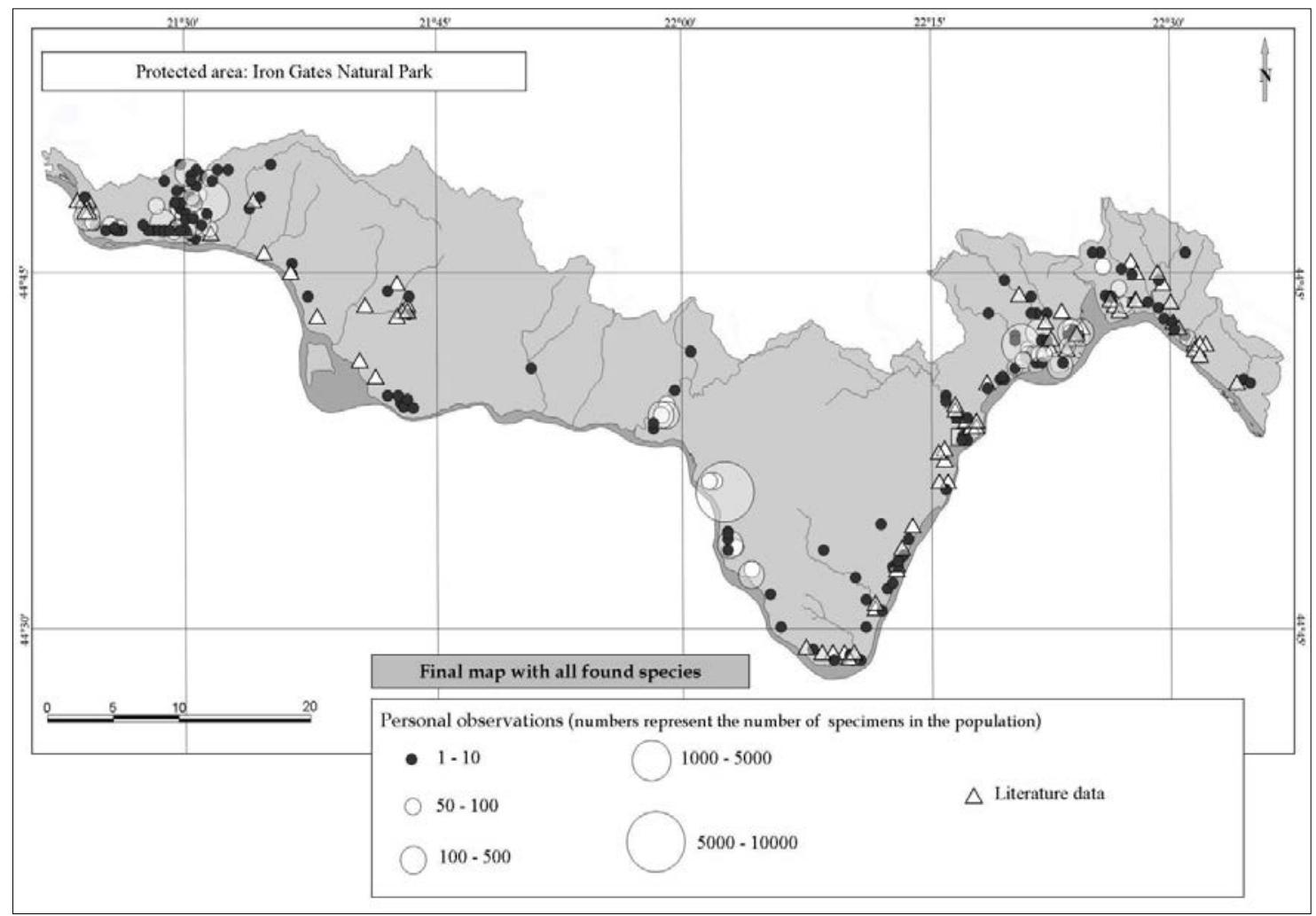

Figure 10: Distribution of orchid species and populations - "Iron Gates” Nature Park (original).

Measures proposed for the protection and sustainable preservation of the Orchidaceae L. species in the "Iron Gates" Nature Park

Consulting the Management Plan (2011) for the "Iron Gates" Nature Park, I found that only a relatively small area of the park benefits from integral protection measures (basically, the natural reservations within the park have been included).

A significant number of habitats of grasslands and forests, where I discovered a high number of orchid species (and implicitly, extensive populations) and other cohabiting floral and faunal elements, extremely important from the biodiversity preservation perspectives, are still not included in the integral protection areas.

Therefore, analyzing strictly the data collected in the field, I propose for evaluation and approval to the administration of the park (the Park Scientific Council, respectively), the following localities and areas which, from the biological diversity point of view, fully comply with the requirements for the integration into the integral protection areas, being thus able to have a proper status. A large part of these areas is currently subject to extreme severe anthropogenic disturbance (the area of the Sfânta Elena karst plateau, the area of Eşelniţa township). 
Proposals for the expansion of the integral protection area (consisting in the proposed map - purple coloured areas, figure 11):

Western area of the "Iron Gates" Natural Park: a. dry grasslands from Topovište and Govedarište (area of Baziaş Village); b. grasslands and the underbrush and scrubs at the south of the Baziass Natural Reservation, stretched over its entire length, up to the limit with DN 57A; besides the orchid species and other rare plants and the vegetal associations belonging to the sub-Mediterranean type, the area shows an important habitat for Horned Viper (Vipera ammodytes) and Hermann's Tortoise (Testudo hermanni); this area also fosters a significant number of Paeonia officinalis ssp. banatica specimens; c. semi-natural and natural grasslands at the north and east of Divici Village; $\mathbf{d}$. grasslands and meadows between Potok Valley and Belobreşca Valley (Ceroviţa Hills); e. the beech and oak forests located in the Potok Valley (between Divici and Belobreşca Villages); f. grasslands and underbush and scrubs at the NE of Belobreşca Village (Tavančic, Mala Lokva Hills); g. grasslands and meadows at the north of Şuşca Village (Movila Strejerica Hill); $\mathbf{h}$. the hill cliffs covered by dry grasslands, on the left exit road from Măceşti Village to Moldova Veche locality; i. grasslands and underbrush located on the Livadika limestone plateau (at the south of Sfânta Elena Village) close to "Feţele Dunării" cliff; j. grasslands and meadows in the sinkholes area of Sfânta Elena limestone plateau (currently, a large part of this area has been destroyed and transformed into a huge wind farm); k. wet grasslands on the left side of the Liuborajdea (Strenjak) Valley;

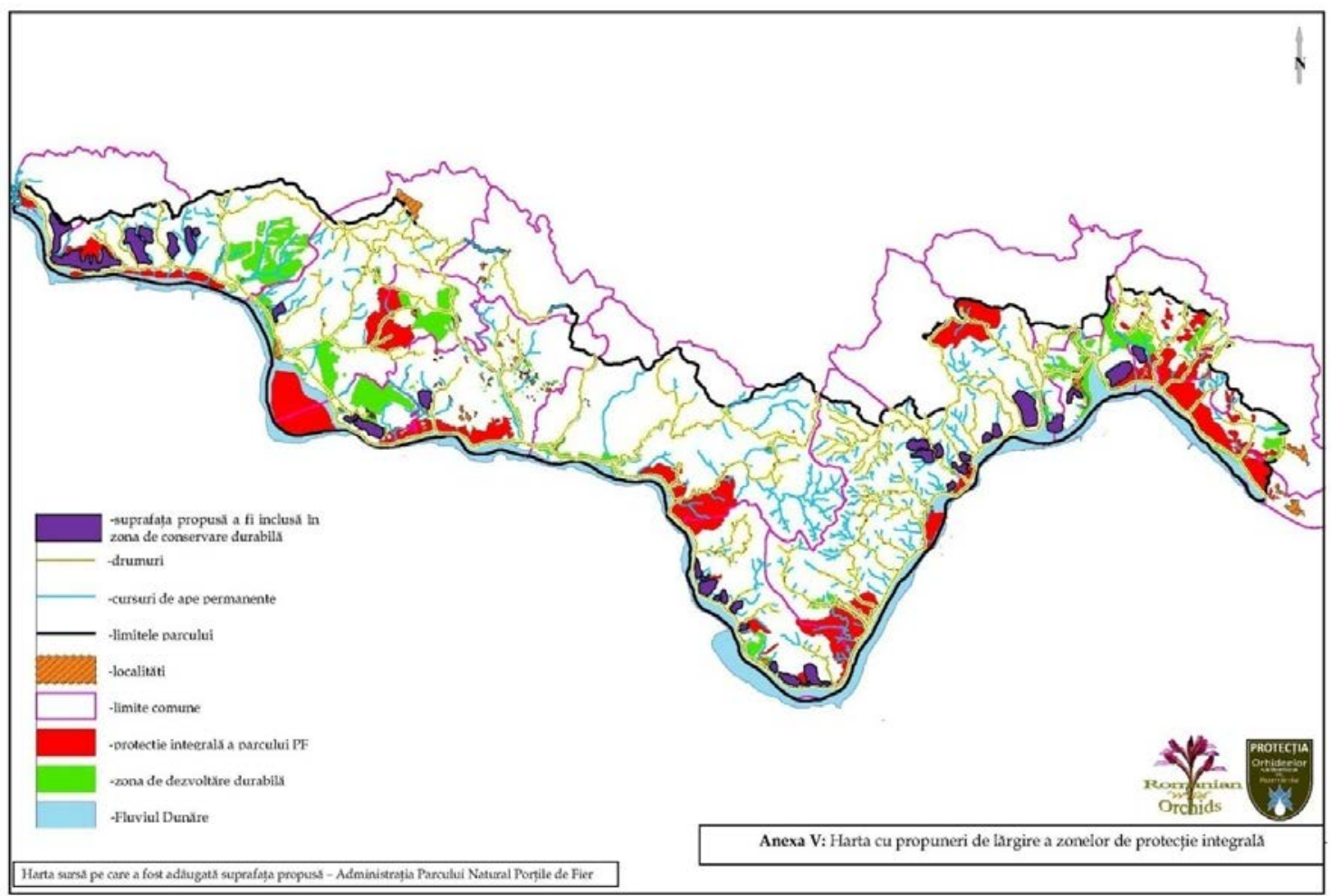

Figure 11: Proposals for the expansion of the integral protection area - "Iron Gates” Natural Park (map source: “Iron Gates” Nature Park Administration). 
Central area of the "Iron Gates" Nature Park: a. grasslands and meadows, the ancient beech and oak forests in the Sirinia Valley (to Bigăr Village, already included into the integral protection area of the "Iron Gates" Nature Park); all grasslands (from the main peaks to DN 57) from the Polesava (Ielişova, respectively) creek up to the small valley of the Povalina Creek (including also the grasslands from the area of the Treskovac Peak); c. all grasslands and the scrub and underbrush (shiblyak type scrub) at the SE of Sviniţa township, Cioaca Boštica area, Tri Kule up to DN 57; d. beech forests, peaks covered by oak trees from the Mraconia Valley;

Eastern area of the "Iron Gates" Nature Park: a. all grasslands on the left banks of the Mrakonia Bay; the grasslands towards Vulcan Hill (at the north of the Cazanele Mici Reservation) from the built-up area of Eşelniţa township; c. the grasslands and scrub in the Mala area (Eşelniţa); d. the grasslands and scrub in the adjacent area of Eşelniţa township; e. the grasslands and oak forests from Eşelniţa township and Orşova municipality; f. the grasslands on Alion Hill (Orșova); g. the grasslands in the Ţarovaţ and Gârbovac Valley (Iloviţa Village).

\section{CONCLUSIONS}

This study aims to render a general exhaustive approach of all terrestrial orchid species that grow in Romania, starting from the morphological features to the particularities related to their biology and ecology, followed by a comprehensive study of the detailed orchid species found in the Danube Gorge ("Iron Gates” Nature Park) area.

In respect of the distribution (corology), ecology and preservation of the terrestrial orchid species growing in the South-West of Romania (the southern region of Banat, respectively), we can draw few conclusions.

Based on the data provided by the scientific literature, I determined that 39 orchid species are present in the southern region of Banat (29 are growing in the "Iron Gates" Nature Park, from the 58 species currently acknowledged in Romania).

During my personal researches conducted in the field for over 15 years, I acknowledged the presence of 23 orchid species in the Danube Gorge area ("Iron Gates" Nature Park).

I established the presence of new orchid species in the research area: two new species in the Danube Gorge area ("Iron Gates" Nature Park): Epipactis purpurata Sm. and Listera ovata (L.) R. Br.

I found orchid species in almost all existing types of natural habitats within the two research areas (except for the steep rocky habitats). An interesting aspect is the fact that no species belonging to the genus Dactylorhyza was found in the Danube Canyon area (no scientific data and no findings during the researches in the field).

The orchid species have been found in 30 vegetal associations, for the "Iron Gates" Nature Park.

The highest number of orchid species, characteristic of open habitats, such as the grasslands, is found in three representative vegetal associations: Danthonio Chrysopogonetum (nine species), Festucetum valesiaco - rupicolae (nine species) and Festuco (rubrae) - Agrostietum (nine species). As for the various forest habitats, a significant abundance of orchid species was found in the: Carpino - Fagetum (13 species) vegetal association. 
The orchids represent rare species (some very rare) in the area of "Iron Gates" Nature Park, subject to my research. For example, in the Danube Gorge, the largest representation (by number) is attributed to the species Anacamptis morio, with an estimate of 20,000 specimens, followed by Anacamptis papilionacea (4,000), A. coriophora and Limodorum abortivum with populations of about 3,000 specimens each (Fig. 9). until June.

A major part of the orchid species present in the research area are in bloom from April

Unfortunately, the actual status of the protection measures taken not only for the orchid species but for all other rare plants (including their habitats), and which are growing within the two protected areas can hardly be considered satisfying.

One of the most important problems that lead to the degradation of the natural habitats from the two protected areas, and which was observed in the field, was the change of land use (an irreversible change, in my opinion, by building holiday homes, wind farms, stone quarries, etc.) followed by the illegal collection of samples, even more destructive.

Taking into consideration the aspects described by this study, it is obvious that the preservation of orchids is not possible without the durable preservation of their natural habitats. In order to provide the proper protection of every separate orchid species found in the two areas subject to my research, the administrators of these areas should be contacted for setting forth the necessary steps to be followed for the integral preservation (as far as this is possible) of the habitats where these rare species are growing.

A significant number of habitats of grasslands and forests ("Iron Gates” Nature Park), where I found a large number of orchid species, does not yet benefit from integral protection measures. Therefore, after a thorough assessment of the data I collected in the field, I propose, for analysis and approval by the administration of the "Iron Gates" Natural Park, 21 new areas which I consider necessary to be included in the park's integral protection system.

In my opinion, the presence of orchids is a sign of a well-preserved habitat and, at the same time, a significant market of the proper state of preservation of the existing biodiversity (the undisturbed intra- and interspecific relationships).

The researches will continue especially due to my passion for studying this very interesting and exciting family of plants. Being fully aware of the orchid flora (presence and distribution) in the south-western part of Romania, I have all necessary arguments for the next stage: protection and durable preservation of the habitats where orchid species grow. I actively try, as far as I possibly can, to engage the attention of the public, to make a small contribution towards stirring public awareness regarding the necessity to protect not only this group of plants but the entire natural heritage of Romania, which is currently facing a potential irreversible downfall for the future generations who, hopefully, will be more responsible. 


\section{REFERENCES}

1. Arditti J., 1992 - Fundamentals of Orchid Biology, New York, Wiley, 704

2. Boşcaiu N., Lupşa V., Resmeriţă I., Coldea G. and Schneider E., 1971 - Vegetaţia lemnoasă mezo-xerotermă (Orno-Cotinetalia) din Defileul Dunării, Ocrotirea Naturii, 15, 1, 49-55, Bucureşti. (in Romanian)

3. Braun-Blanquet J., 1965 - Plant Sociology: The Study of Plant Communities, London, Hafner, 439.

4. Buttler K. P., 1986 - Orchideen, die wildwachsenden Arten und Unterarten Europas, Vorderasiens und Nordafrikas, Mosaik Verlag, Munchen, 287. (in German)

5. Ciocârlan V., 2009 - Flora ilustrată a României, Pteridophyta et spermatophyte, Edit. Ceres, Bucureşti, 1141. (in Romanian)

6. Coste I., 1974 - Flora şi vegetaţia Munţilor Locvei, Teză de doctorat, Universitatea "BabeşBolyai” Cluj, Facultatea de Biologie - Geografie, unpublished. (in Romanian)

7. Csürös Ş., Pop I., Hodişan I. and Csürös-Kaptalan M., 1968 - Cercetări floristice şi de vegetaţie între Orşova şi Eşelniţa, Contribuţii botanice, 277-312, Cluj Napoca. (in Romanian)

8. Delforge P., 2006 - Orchids of Europe, North Africa and the Middle East, A \& C Black, London, 640.

9. Dihoru G. and Negrean G., 2009 - Cartea roşie a plantelor vasculare din România, Edit. Academiei Române, Bucureşti, 630. (in Romanian)

10. Dressler R. L., 1981 - The orchids: natural history and classification, Cambridge, Massachusetts, Harvard University Press, 352.

11. Dressler R. L., 1993 - Phylogeny and classification of the orchid family, Dioscorides Press, 352.

12. Gladkova H. V. and Tahtadžan A. (eds), 1982 - Semenstvo orhidnie (Orchidaceae), Žizn rastenii, 6, 248-275. (in Russian)

13. Grigore S. and Coste I., 1974 - Aspecte botanice din rezervaţia naturală Valea Mare-Moldova Nouă, Ocrotirea Naturii, 18, 2, 159-166. (in Romanian)

14. Grigore S. and Coste I., 1975 - Flora Rezervaţiei Naturale Valea Mare - Moldova Nouă (Banat), Tibiscus, Ştiinţe Naturale, 69-81, Timişoara. (in Romanian)

15. Grigore S. and Coste I., 1978 - Cercetări asupra vegetaţiei dintre Moldova Veche şi Pescari (judeţul Caraş-Severin), Banatica, Caiete de Ştiinţe naturale, Studiile Cercului de Geolgie Geografie şi Biologie, 7, 173-189, Reşiţa. (in Romanian)

16. Heuffel J., 1858 - Enumeratio Plantarum in Banatu Temesiensi, Vindobonae, 208.

17. Jávorka S. and Csapody V., 1934 - A magyar flóra képekben, Studium, Budapest, 576. (in Hungarian)

18. Matacă S., 2005 - Parcul Natural Porţile de Fier, Flora, Vegetaţia şi Protecţia Mediului, Edit. Universitară, Craiova, 549. (in Romanian)

19. Milanovici S., 2003 - Rod Orchis na južnim padinama planine Lokva (Đerdapska Klisura Porţile de Fier) Rumunija, Diplomski rad (Licence Paper), Univerzitet u Novom Sadu, PMF Departman za Biologiju i Ekologiju, Novi Sad, Srbija, 60. (in Serbian)

20. Milanovici S., 2004 - Genul Orchis L. pe versanţii de sud-vest al Munţilor Locvei (Parcul Natural Porţile de Fier), Drobeta, seria Știinţele Naturii, XIV, 36-38, Drobeta Turnu Severin. (in Romanian)

21. Milanovici S., 2006 - Orchids from "Iron Gates” Natural Park area, distribution and conservation problems (Romania) Caesiana, The Journal of the European Orchid Council, Edit. Borgia, Roma, Padova, 99-104.

22. Milanovici S., 2009 - Considerations regarding conservation of orchid's species in "Iron Gates" Natural Parc area, Drobeta, Seria Știinţele Naturii, XIX, 29-43, Drobeta Turnu Severin.

23. Milanovici S., 2012 - Orhidee din sudul Banatului (English - Orchids from south-west side of Banat region), East-West Print, Timişoara, 406. (in Romanian)

24. Nilsson L. A., 1992 - Orchid Pollination Biology, Trends in Ecology and Evolution, 7, 8, 255259. 
25. Oltean M., Negrean G., Popescu A., Roman N., Dihoru G., Sanda V. and Mihăilescu S., 1994 Lista Roşie a plantelor superioare din România, Studii, sinteze, documentaţii de ecologie, 1, Bucureşti, 54. (in Romanian)

26. Panţu Z., 1915 - Orchidaceele din România. Studiu Monografic, Edit. Acad. Rom., Bucureşti, 225. (in Romanian)

27. Pătroescu M., Chincea I., Pascovici N., Ioja C., Matacă S., Popa E. M., Florescu V., Dumitraşcu D., Vâlceanu C., Odorescu I., Popescu V., Rozylowicz L., Necşuliu R. and Sbîrcea Ş., 2004 Planul de management al Parcului Natural Porţile de Fier în perspectiva dezvoltării durabile, Drobeta, Muzeul Regiunii Porţile de Fier, XIV, 64-92, Drobeta Turnu Severin. (in Romanian)

28. Rasmussen H. N., 1995 - Terrestrial orchids from seed to mycotrophic plant, Cambridge University Press, 460.

29. Roman N., 1974 - Flora şi vegetaţia din sudul Podişului Mehedinţi, Bucureşti, 222. (in Romanian)

30. Rochel A., 1828 - Plantae Banatus rariores iconibus et desarepteniobus illustratae, Pestini;

31. Sanda V., Öllerer K. and Burescu P., 2008 - Fitocenozele din România. Sintaxonomie, structură, dinamică şi evoluţie, Edit. Ars Docendi, Universitatea din Bucureşti, 570. (in Romanian)

32. Savić D., 2001 - Orhideje Fruške-Gore, Magitarski rad, Beograd, 221. (in Serbian)

33. Soó R., 1973 - A magyar flóra és vegetáció rendszertani - növényföldrajzi kézikonyve v. Akadémiai Kiadó, Budapest, 723. (in Hungarian)

34. Souche R., 2004 - Les Orchidees sauvages de France, Pelican, Montpellier, 340. (in French)

35. ***, 1964-1980 - Flora Europaea, I-V, Cambridge University Press, Cambridge, V-476.

36. $\quad * * *$, Flora R. S. R. - XII, 1972, Edit. Academiei R. S. R. (in Romanian)

37. ***, 2011 - Administraţia Parcului Natural Porţile de Fier, Planul de Management al Parcului Natural Porţile de Fier, Orşova, 320. (in Romanian)

38. Herbarium Vlaicu N., Muzeul National al Banatului, exs., Vlaicu, 1985

39. IUCN Red List of Threatened Species. Version 2011.1., www.iucnredlist.org. Downloaded on 22 October 2011

40. CITES, 2011. http://www.cites.org/eng/app/appendices.php accessed on October 25th 2011 